DOI https://doi.org/10.18551/rjoas.2016-12.23

\title{
EXTRA-ROLE BEHAVIOR MODELLING: PERSONALITY CONCEPT AND THE ROLE OF SERVANT LEADERSHIP
}

\author{
Ismail Verni Y.*, Armanu, Hadiwidjojo Djumilah, Indrawati Nur Khusniyah \\ Faculty of Economics and Business, University of Brawijaya, Indonesia \\ *E-mail: verni.yuliaty@yarsi.ac.id
}

\begin{abstract}
Nowadays, extra-role behavior has become one of the important outcomes for organization. Because in order to achieve their success; organizations need employees who are willing to do more work than what they are supposed to do. The purpose of this article is to develop extra-role behavior model based on personality concept as employee's internal factor, and the role of servant leadership in organizational environment. Personality concept is developed using two approaches, namely traits approach and cognitive social learning approach. Extra-role behavior appears as the influence of individual internal factors that are agreeableness and conscientiousness personality which is sharpened by the combination of developing process of self-efficacy and spiritual motivation. Leadership factor acts as one of the important external factors in organizational environment which functions as factor that directs employee's personality to be willing to do extra-role behavior. The extra-role behavior model produced is that servant leadership roles as moderator of conscientiousness, agreeableness, self-efficacy personality and spiritual motivation that influences the employee's extra-role behavior.
\end{abstract}

\section{KEY WORDS}

Extra-role behavior, leadership, agreeableness, conscientiousness, self- efficacy, spiritual motivation.

The performance of employee decribes the contribution given by individuals for the organization that employed them. Generally, performance assessment means executing evaluation of present and/or past performance of the employees to see if it is relative to their work performance standard (Dessler, 2014). Different from the formal performance assessment system which is based on determined task and result standard, Stewart \& Brown (2011) made citizenship performance and task performance as important elements in describing the whole employee's performance which contributes to the organization.

Robbins \& Judge (2015) developed organization behavior model by inserting Organizational Citizenship Behavior (OCB) or extra-role behavior as one of the outcomes of the input and the process of behavior happened in organization. Extra-role behavior becomes one of the important outcomes because a successful organization needs employees that will do more work than their usual tasks - that will produce something surpasses the expected performance. Organization wants and needs employees who are willing to do works which are not only in the job description. Organization needs employees that behave as good citizenship that excersice extra-role behavior.

Extra-role behavior is a free individual behavior, not directly or explicitly known by formal remuneration system, and simultaneously increasing the organization's function effectively (Organ, 2006). The development of extra-role behavior was starting on 1980s, stated by Organ and colleagues. Extra-role behavior considers the social structure which is rooted from approach that specifically related to the spontaneous act of human (Katz and Kahn, 1966). This behavior is called extra-role behavior by Katz (1963) or organizational citizenship behavior (OCB) by Bateman and Organ (1983) (Vigoda-Gadot, 2006).

Theoritically, these spontaneous behaviors play a key role in increasing effectiveness, efficiency, and positive climate in work environment. Therefore, managers and employees are encouraged to increase their voluntary activity in organization which is perceived to be 
able to increase a healthier work environment, direct to the escalation of work result, and increase the achievement of organization's purposes overall. Citizenship performance is a behavior that contributes toward social and psychological environment of organization (Stewart \& Brown, 2011).

Extra-role behavior is considered as pro-social behavior (Penner et al, 2005). It is behavior that illustrates category of action which is defined by several social segments as behavior that benefits other people. In individual level, extra-role behavior can increase employee's work satisfaction (Hall et al, 2009), reduce work stress (Tziner \& Sharoni, 2014) and reduce intention of employee to resign from company (Alfes et al, 2013). The consequence of extra-role behavior can also give benefit to the enhancement of product quality (Cheng-Cheng, 2012) or benefit for consumer in form of service quality enhancement (Djati, 2008) and consumer's satisfaction (Suthatdjana, 2013) which later can increase consumer's loyalty toward the product or service offered by the company. Overall, in the end, extra-role behavior gives contribution toward sales performance (Jaramillo, 2009), or organization performance in general (Zheng-long, 2012; Changquan \& Hardie, 2009).

Based on behavior model developed by Robbins \& Judge (2015), the main subject of concern, as input to produce outcome is human or employee, both employees as individual with all internal attributes attached to them and employees when they are interacting with external attributes attached to group and organization environment. The occurrence of employee's behavior in producing outcome will undergo process, both processing their internal attribute in any situation faced and responding external attribute on group and organization level. At individual level, extra-role behavior is included in deep-level diversity category. Individual diversity at deep-level diversity, that gains quite attention to study extrarole behavior is personality.

Purba \& Seniati (2004) stated that personality is expected to be a better predictor of employee's performance. The management's expectation of employees is so that they do not only show in-role performance, but also extra-role performance. People's way in treating their environment is partly the result of their behavior. How people behaves is partly the result of how other people treat them (Burger, 2011); this includes leaders that become superior's of the employees. Leadership is external attribute at group and organizational level that functions to mobilize employees to achieve organization's purposes (Robbins \& Judge, 2015). This approach explains that personality traits can develop because there is a learning process happened as the result of people's interaction with their environment. It is called superior's leadership function. The purpose of this article is to develop extra-role behavior model based on the role of servant leadership as moderator of employee's personality concept, which consists of conscientiousness, agreeableness, and self-efficacy and spiritual motivation variables.

Extra Role Bahavior. Extra-role behavior originates from approach that specifically related to human's spontaneous action to do something beneficial for others (Katz and Kahn, 1966). Extra-role behavior was introduced for the first time by Organ in 1977 by term 'organizational citizenship behavior' or OCB (in Vigoda-Gadot, 2006). According to Organ (1988), organizational citizenship behavior was defined as individual trait that is voluntary, indirectly or explicitly known in formal remuneration system, and in overall increase the effectivity function of organization.

Employees with high extra-role behavior are willing to be more involved in organization, and tend to involve in giving back to organization (Organ, Podsakoff, MacKenzie \& 2006). It means extra-role behavior is beyond the role needed in organization, and in the end this behavior will benefit the organization. This behavior is declared as the behavior that can preserve and escalate social and psychological context that support the performance of organization's members to do their job. Thus, extra-role behavior is a separate construction from task behavior construction or in-role. Extra-role behavior involves unrequired behavior from an employee in doing certain job, but it is still displayed by organization's members to increase work quality and indirectly increases the organization's effectivity.

Extra-role behavior concept that is treated most consistently by researchers compared to other extra-role behavior concept is extra-role behavior concept of Organ. According to 
Organ (1988), extra-role behavior consists of altruism, coutesy, sportsmanship, conscientiousness and civic virtue dimensions. Altruism is related to the behavior of helping other people in organization in real action. Courtesy is behavior of helping colleagues to prevent problem occurrence which is related to work by giving information and consultation needed by colleagues. Conscientiousness means doing things that will benefit the organization more than it is required from their job, such as obeying organization's regulation even though it feels uncomfortable, being initiative to do improvement to increase self and group performance, and volunteering in taking extra responsible at work. Sportsmanship is tolerance at less ideal situation at work place without complaining and be positive even though everything does not run properly. Civic virtue is behavior that shows involvement in organizational activities and concerns on organization viability.

Stewart \& Brown (2011) brought up different extra-role behavior concept. Citizenship performance is conducted to fully help organization or specifically help individual. Everything which is done to benefit organization is called organizational citizenship behavior. Examples of this type of performance are when employees do something to protect the property of organization, giving information when they do not attend work, and obey informal regulations that help maintaining order. Other behavior is called interpersonal citizenship behavior. It has influence that specifically benefits other people. Examples of this kind of behavior are sparing time to listen to other colleagues' problems, giving information to their colleagues, and helping handle other people's work that cannot attend work.

The Influence of Personality Internal Factor toward Extra-Role Behavior. Personality is consistent behavior patterns and interpersonal process originated within individual (Burger, 2011). This definition consists of two aspects that can describe personality. Firstly, consistent personality, which is same behavior patterns that will appear anytime and in any situation. However, this consistent aspect of this personality does not mean that people cannot change. Second, interpersonal process is emotional, motivational and cognitive process within individual that influences themselves to act and feel something.

There are six personality approach models that can be a reference to behavior patterns and consistent interpersonal process (Burger, 2011). Based on this approach combination, a broader and more accurate description about how people behave the way they are can be obtained. Psychoanalitic approach argues that human's unconscious mind is mostly responsible for the crucial difference in their behavior. Next, trait approach identifies that a person consists of varies personality characteristic continuum. Biologic approach refers to inherited predisposition and physiological process to explain the difference of individual personality. In contrary, humanistic approach identifies personal responsible and selfacceptance as the key that causes differences in personality. Behavioral/social learning theory explains consistent behavior patterns as the outcome of conditioning and expectation, while cognitive approach see difference in the way of people process information to explain the difference in behavior.

There are various personality factors used by researchers to see its role toward extrarole behavior. There is still no one entity concept about personality role in forming extra-role behavior. The Big Five Personality Model is the most popular Personality Traits Theory used in work environment. It includes research about extra-role behavior in organization. Personality trait is personality dimension used to categorized people based on certain level characteristic shown by the people itself (Burger, 2011). The Big Five Personalities are neuroticism, extraversion, openness, agreeableness, and conscientiousness (Schultz \& Schultz, 2013).

The difference of the usage of personality variable in research about extra-role behavior based on The Big Five Personality Model is seen in the characteristic usage of the model itself. For example, research that uses the five characteristics in The Big Five Personality Model (Purba \& Seniati, 2004; Mahdiuon, 2010; Darsana, 2013), Big Five Personality plus honesty-humiliaty trait (Bourdage et al, 2012), and Hwee Hoon Tan \& Min Li Tan (2008) only used conscientiousness dimension in their research. Darsana (2013) and Herman (2013) conducted research on employee's personality as single factor of The Big Five Personlity Model, thus it only found out if personality influences extra-role behavior or 
not. This method cannot see the influence of each personality trait toward extra-role behavior. It is different from the research by Bourdage et al (2012) which analizes the influence of each personality trait toward extra-role behavior.

Other researches about extra-role behavior uses different personality variable, outside The Big Five Personality model, such as the research that see the influence of self-efficacy (Pavalache-llie, 2014), work locus of control (Magdalena, 2014; Pavalache-llie, 2014), or motivation (Djati, 2008) toward extra-role behavior. It can be seen that the researchers have different opinions in using this personality factor. Beside that, the research about extra-role behavior also uses personality factor partially, both The Big Five Personality Model and other approaches.

Several researchers use The Big Five Personality Model by seeing only personality traits that significantly influence extra-role behavior (Mahdiuon et al, 2010; Purba \& Seniati, 2004). It means that this method is kind of exploration to search for personality traits that influence extra-role behavior. The research result shows that the main characteristics which influence extra-role behavior are extraversion, openness to experience and conscientiousness (Purba \& Seniati, 2004); Agreeableness, openness to experience, and conscientiousness (Mahdiuon et al, 2010). Hwee Hoon Tan \& Min Li Tan (2008) only used personality trait conscientiousness of The Big Five Personality Model. They focused on conscientiousness because according to them, this trait is the most consistent predictor toward various job criterias. Penner et al (2005) showed that agreeableness dimension of the Big Five Personality theory enables the occurrence of tendency to act pro-socially (extra-role behavior).

The Big Five Personality: Conscientiousness dan Agreeableness. Personality trait is a tendency to give response, with same or similar behavior, toward different stimulus. In other words, trait is consistent and permanent ways of people in reacting toward their environment (Schultz \& Schultz, 2013). Trait changes according to the situation. Allport brought up the two types of traits; they are individual and common. Individual traits are unique and define one's character. Common traits are shared nature of a group of people, like a part of certain culture. Thus, people with different cultures will also have different shared natures. Common traits can possibly change through times when social standard and values changed. This shows that common traits are originated from social, environment and culture influence.

The application of The Big Five Model personality in work environment has been shown by researchers by correlating personality and work performance (Burger, 2011). Based on the characteristics of The Big Five personality Model, conscientiousness is the best determining factor of work performance. The reason is because people with high conscientiousness are normally cautious, careful, and reliable. They do not rush in finishing a task, but they need time to be able to do their work correctly and perfectly. People with high conscientiousness tend to be organized people and have detail plan before they start a big project. These people are also hard-worker, persistent and success oriented.

Conscientiousness cannot be said as the only dimension of The Big Five Personality which is connected to work performance. Agreeableness is also a factor that is connected to work performance. People with high agreeableness are helpful, trustable and sympathetic. In contrary, those with low agreeableness tend to be antagonist and skeptical. People with high agreeableness like teamwork more than competition. In contrary, those with low agreeableness like to fight for their own interst and belief. People with high agreeableness have a more enjoyable social interaction and less conflict than those with low agreeableness. They also like to help people in need.

Self-Efficacy. Modern personality theories develop cognitive social learning approach toward personality. It is an approach that emphasizes on cognitive and social process, in which people learn to appreciate and especially fight for their purposes. One of the most important concepts about Cognitive Social Learning Theory which was introduced by Bandura on 1986 is self-efficacy (Larsen \& Buss, 2010).

Schultz \& Schultz (2013) referred self-efficacy as adequate, efficient, and competent feeling in facing life. Self-efficacy can also be explained as a perception toward control that people have over their own life. Their ability to influence outcomes makes it predictable. The 
ability to predict outcome can help to prepare what is needed. Fulfilling and preserving performance standard can escalate people's self-efficacy, while failure in fulfilling and maintaining it can lessen their self-efficacy.

People with high self-efficacy believe that they are able to confront events and situations happening effectively. They expect to succeed in solving problems; they are diligent in doing their work and often achieve high work performance. People like this have a high confidence compared to those who have low self-efficacy (Madduz, 2012). Believing that people have the ability to be success is a great asset as long as they fight to achieve it (Schultz \& Schultz, 2013).

Spiritual Motivation. Motivation concept is part of personality theory. The influence of the current situation on a person is not only on their personality, but also his point of view about motivation. What people want and what they fight for is the key to understand their behavior. Therefore, intentional intention is an essensial part of personality. The power of motivation of emotionally mature and healthy people is something autonom or independent (Schultz \& Schultz, 2013). 'Propriate functional autonomy' process is an essensial to understand motivation. Propriate motives are something unique within person. People will maintain motives that will escalate their self-esteem or self-image. Thus, there is a direct connection between people's interest and their ability, because people will enjoy something they are really good at. Propriate functioning is a process that preserves sense of self, that determine how people perceive the world, what they remember their experiences, and how their mind is directed. This perceptual and cognition process is selective, chosen from series of stimulus from the surroundings which only relevant with their interests and values they belief.

Religios factor plays important role in personality development. There is a need to combine and learn about a person's religiosity if we want to achieve a full understanding about human's personality (Ryckman, 2008). The developers of personality theory strongly proved that the role of religion in personality development can be studied scientifically. They also think that religion can be source or obstacle for the growth of personality. Constructively, religion can give human series of principles, values and beliefs that help them to successfully overcome stress and action. Religion also gives individual sense of dignity and worth, can help the development of ethical awareness and personal responsible and concern for other people, also gives purpose and meaning to human's life.

Their religious belief helps them to intergrate their personality and generate a consistent morality. The religiosity is based on faith. Each individual have different religios orientation. Each person has different religios orientation. People motivated extrinsically are people that exploit their religion, while one motivated intrinsically is people that live according to their religion (Ryckman, 2008). Basic religios values are made as reference of human's activity. One of it is business. Business spiritual values (religios ethical values), howsoever, must be developed to support the growing process of business and success (Indrawati, 2012).

Wibisono (2003) used aqidah motivation, worship motivation, and muamalah motivation dimension to see the spiritual motivation in a Moslem that makes Islam as their religion in living their life. Aqidah (rules) dimension is concerning life assurance which is faith, a pledge from the heart (instrinsic). Muamalah dimension is observance in broad sense, which is rules that set the relationship between human, and between human with object or natural material. Muamalah regulates primary needs (basic living needs) and secondary needs (pleasures) that are still in the corridor to increase business and performance activity.

Servant Leadership as External Factor Determining Extra-Role Behaviors. The development of personality theory introduces the approach of The Behavioral/Social Learning; a concept about behavior-environment-behavior interaction. Which stated that it is not only environment that influence behavior, behavior will also determine the kind of environment where they are, that later will also influence the person's behavior. People's way in treating other people (their environment), part of it is the result of their behavior. Of course how people acts, part of it is the result of how people around them treat them (Burger, 2011). This approach explains that personality traits can develop because there is learning process 
happening as the result of the people's interaction with environment where they are. Likewise, personality traits which are relatively permanent and becoming their character, can appear in different behavior because it is influenced by the environment situation they face.

Therefore, personality traits that generate extra-role behavior will be influenced by external factor that people face in their working environment. One of external environment factors which plays role in work behavior based on a person's personality is the leader in organization. There are a lot of supporting evidences which prove that leadership style has significant role toward the performance of organization (Sashkin, 2014). According to Kondalkar (2007), the success of organization depends on the efficiency of the leader. Attributes, positive approach, and ability to solve problem are factors that form a person to be a leader. A leader is supposed to be able to motivate the employees because leadership can also be interpreted as influence; a process to influence people around them so that they are willing to work happily and enthusiast to achieve group's purposes.

Researches about the role of leadership to the extra-role behavior had been conducted by several researchers. Those researches were conducted by using various leadership styles. Cheng-Ling (2012) used transformational, transactional and ethical leadership to see the connection with extra-role behavior. Other leadership styles are Leader-Member Exchange (Alfes et al, 2013), authority leadership (Ning Hongyu, 2012), servant leadership (Jaramillo et al, 2009), ethical leadership (Newman et al, 2014), spiritual leadership (Chin-Yi \& Chin-Fang, 2012), and charismatic leadership (Babcock-Roberson \& Strickland, 2010). These researches show the diversities of the use of leadership style variable which can be made as determinant model of extra-role behavior. Researchers are still looking for which superior's leadership styles that influence extra-role behavior of employees most effectively.

Leadership in organization is a process of influencing the members of organization to direct, compose and facilitate activity and relationship happened in the organization (Kondalkar, 2007). Process of influencing the members of organization is expected to be able to drive employees to have working behavior that lead to the individual and organizationanl performance achievement. This mechanism shows that the leadership in organization influences performance as a function that moderates the members of the organization to exercise effective working behavior. Researches that look into the influence of leadership toward extra-role behavior puts leadership factor as the moderator variable. Leadership moderates the influence of Human Resource Management practice (Alfes et al, 2013), working behavior (Jaramillo et al, 2009), collectivism (Ning Hongyu et al, 2012), trust (Ning Hongyu et al, 2012), calling and membership of employees (Chin-Yi \& Chin-Fang, 2012) toward extra-role behavior. It is obvious that there is still no research that looks into the influence of personality factor toward extra-role behavior by using superior's leadership as the moderator variable.

The term servant leadership was first introduced by Robert Greenleaf in 1970s. Leader in any levels of organization, if they simply lead by fulfilling the team's need, then they are called servant leader. In many things, servant leader is a form of democratic leadership because the entire team tend to get involved in the decision making (Ivanko, 2012). Servant leadership is categorized in the theory of authentic leadership. An authentic leader knows who they are, knows what they trust and value, and acts based on it openly and sincerely. The followers consider them as ethical people. The main quality derived by authentic leadership is trust. Authetic leader shares information, encourage open communication and stay attached to their ambition. The result of authentic leadership is people that are loyal to them.

Robbins \& Judge (2015) stated that servant leadership is a leadership style marked by doing something beyond their own personal interest and focusing on the chance to help their followers to grow and thrive instead. They do not use power to reach their purpose, they emphasize on persuasion. The behavior characteristics of servant leader are including listening, emphatizing, encouraging, serving, and actively develop the potential of the followers. According to Yukl (2013), servant leadership in working environment is about helping other people to achieve common purpose by facilitating individual development, 
empowerment and consistent collective work for the long term health and prosperity of the followers.

Extra-Role Behavior Model with Personality Concept and Servant Leadership as Moderator. The development of this extra-role behavior model focuses on the personality concept that uses traits approach by emphasizing the utilization of personality characteristics of The Big Five Personality Model as the determinant of the occurrence of extra-role behavior. Agreeableness and conscientiousness personality characteristic are alleged to be the best determining factor of extra-role behavior. On the other side, theoretically, traits approach is not the only way to find out employees' personality, including seeing the influence toward extra-role behavior. It is a new research gap by including the aspect of personality with cognitive approach in concept of agreeableness and conscientiousness personality. The purpose is to gain a broader and more accurate illustration about why people behave the way they are. Personality characteristic in traits approach is relatively stable personality and formed since the beginning of people's life (Burger, 2011), while personality in cognitive approach shows personality aspect that forms people's self-system from learning process in their environment. Self-system within people appears as selfregulation toward their own behavior in pursuing their life purposes (Larsen \& Buss, 2010).

Researches about extra-role behavior based on employee's personality tend to focus only on the internal factors without any regards of the influence of external factor of organzation's environment. Whereas, based on behavior/social learning approach (Burger, 2011), the personality of employees can form extra-role behavior. It is because there is a learning process happened as the result of the interaction between the employees and the work environment. Leadership in organization is one of external factors that involving process of influencing the employees to behave in certain way (Kondalkar, 2007). Therefore, the purpose of this research is to complete researches about the influence of personality concept toward extra-role behavior, by including external factor leadership style as moderator variable that will encourage the occurrence of extra-role behavior.

Leadership in organization is considered as a process that emphasize on the interaction and social relation happened in a group or organization (Kondalkar, 2007). Therefore, leadership style that is effectively used by leader level in organization mostly will depend on the group or organization environment. The research of Ning Hongyu et al (2012) also showed that extra-role behavior is influenced by culture values evolved in an organization. The occurrence of extra-role behavior will be stronger in organization which collectivism value of the employees is higher than the individualism. Normally, subjects of research about Human Resource management are fixed on organizations which are profit oriented. Research about extra-role bahvior especially conducted on service sector organization (Pavalache-llie, 2014; Afes et al, 2013; Afshardoust et al, 2013; Jain \& Cooper, 2012; Ning Hongyu, 2012; Zheng-long \& Hong-dan, 2012; Jaramillo et al, 2009;), and specifically in education institution with teachers as the subject (Magdalena, 2014; Ahmadizadeh, 2012; Sesen \& Basim, 2012; Farooqui, 2012; Mahdiuon, 2010; Mayfield \& Taber, 2010).

The development of this model is meant for employees at Islamic Micro Finance Institution. As an institution which stands for economic welfare of the lower class community that works with principle to come directly to the society, thus it needs managers with high work commitment and individuals with high social concern. The motivation of Islamic Micro Finance Institution to work in workship frame and seek for Allah's blessings is materialized in Islamic values which are implanted by the founder of Islamic Mirco Finance Institution to all the employees (Ismail, 2015). Islamic Mirco Finance Institution also tends to have high collectivism culture. Referring to the collectivism culture of organization and the social function attached to Islamic Mirco Finance Institution, aside its business function, therefore the leadership factor that will be considered as moderator variable is servant leadership style. The inclusion of spiritual motivation as research's variable which based on Islamic values has become the characteristic of this Islamic Micro Finance Institution. Motivation concept is a part of personality theory because the influence of the current situation on a person is not only on the personality, but also the point of view about motivation. Religiosity 
in people's life is considered to be important if they want to reach an intact understanding about human's personality.

Leadership with servant leadership style, just like charismatic leadership, theoretically also considered as part of transformational leadership. The difference is servant leadership uses relationship approach between leader and follower. Serving 'the follower's need' becomes the priority of leader and makes it as purpose, not as process to achieve organization's purpose (Jarmillo et al, 2009). A servant leader tends to empower the followers more than using authority to dominate them. Trust is fully built with honesty and openness, act with values consistently, and show trust toward their followers. Leader with servant leadership must hold on to what's good and right, even when what's good and right is not for the benefit of the organization. Injustice and social differences must be fought if necessary. Even the weakest and marginal member of society must be treated respectfully and with honour. This leadership approach is more appropriate for research environment in BMT which has two functions, which are business and social function. It is possible that this servant leadership style will lead the internal aspects of administrator to exercise extra-role behavior.

\section{CONCEPTUAL FRAMEWORK}

Conceptual framework for the development of this extra-role behavior model is made by using three viewpoints. First, the usage of personality concept with trait and cognitive approaches. Personality with traits approach uses agreeableness and conscientiousness personality traits of The Big Five Personality Model as determining factor of extra-role behavior. Personality concept is developed by including personality element with cognitive approach. Cognitive approach in personality shows a contemporary aspect of a person in looking at the future. Thus, self-efficacy and spiritual motivation are used in the personality concept.

Second, the usage of servant leadership style as moderator variable. Servant leadership style is used as moderator variable of personality in influencing extra-role behavior. Research about the influence of personality toward extra-role behavior tends to see the direct influence of the two variables. Based on The Behavioral/Social Learning approach, personality will influence people's behavior as their learning result when they are interacting in their social environment. In the perspective framework, this research has made servant leadership as external factor in working environment that serves as moderator between personality and extra-role behavior.

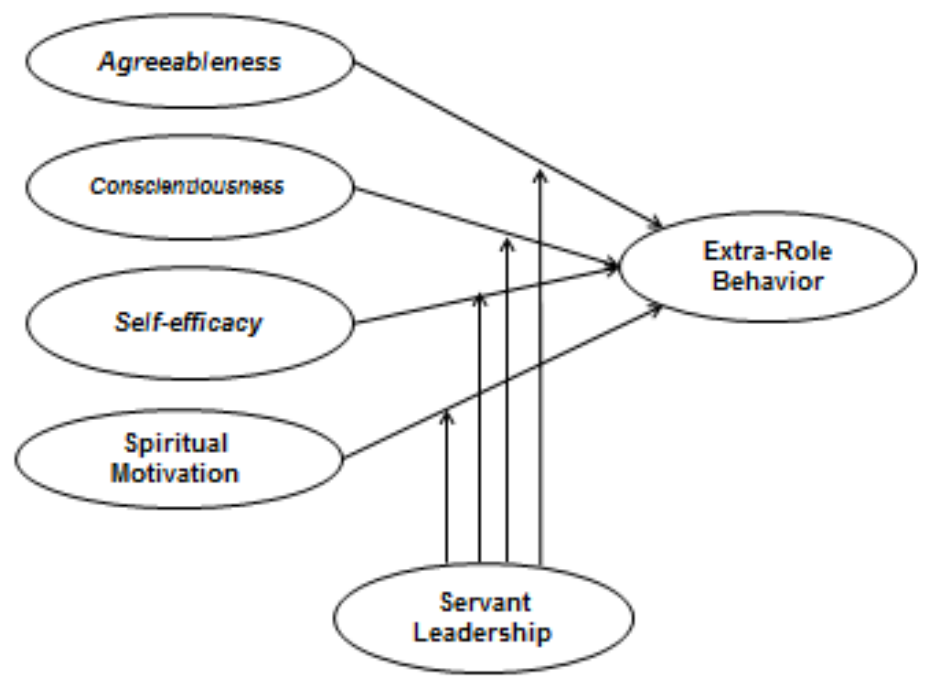

Figure 1 - Conceptual Framework 
Third, the subject of organization with Islamic based with business and social orientation. Normally, research on Human Resource management is conducted in profit oriented organization and some in non-profit organizations. This research was done to cover the scarcity of human resource's research in organization with Islamic based. That is the organization that has business and social orientation, by using Islamic microfinance institution as the research subject. Explanation that describes the relation between research variable in form of conceptual framework can be seen in Figure 1.

Agreeableness Personality and Extra-Role Behavior. According to Burger (2011), agreeableness personality also related to duties performance at work place. Individuals with high agreeableness personality are trustful, cooperative and helpful. They are people who like to work, especially to be able to work well for assignment in team work. People with high agreeableness have more enjoyable social interaction and less conflict than those who are low in this dimension. They are also willing to help people in need. Thus, employees with high agreeableness tend to be willing to do extra-role behavior, especially behavior that related with other individual. Research result also shows that agreeableness personality has positive relation with the occurrence of extra-role behavior, as mentioned by Bourdage et al (2012); Mahdiuon (2010); Leephaijaroen (2016); Kiffin-Petersen, Jordan, and Soutar (2011). Therefore, it can be predicted that agreeableness personality has positive influence toward extra-role behavior.

Conscientiousness Personality and Extra-Role Behavior. Among the five personality characteristics of The Big Five Personality, conscientiousness is the best determining factor of task performance (Burger, 2011). People with high conscientiousness are people who tend to be cautious in acting, careful and reliable. They are not rushing in completing task because they need time to do their job correctly and perfectly. People with high conscientiousness tend to be well organized in working and have detail plan before starting a big project. These individuals are also hard-working, persistent, and oriented on success. Cosncientiouness personality which is shown by traits such as organized in working, hardworking and oriented on success is predicted to be more willing to exercise extra-role behavior than employees with low conscientiousness, especially behavior that shows their concern toward organization. Research results of Mahdiuon (2010); Hwee Hoon Tan \& Min Li Tan (2008); Leephaijaroen (2016); Debusscher, Hofmans, and De Fruyt (2016), and KiffinPetersen, Jordan, and Soutar (2011) showed that there is a positive connection between conscientiousness personality and the occurrence of extra-role behavior. Therefore, the statement about the relation between variables of conscientiousness personality and extrarole behavior is that conscientiousness personality has positive influence toward extra-role behavior.

Self-efficacy and Extra-Role Behavior. People's self-efficacy directs employees to have a better work performance. People with high self-efficacy believe that they can face happening event and situation effectively. They hope they can solve problems. They are diligent people who do their jobs and often achieve high work performance (Schultz \& Schultz, 2013). People like this have a hig confidence of their ability compared to those with low self-efficacy. Self-efficacy and performance are influencing one another. Self-efficacy guides people to a better performance, likewise good performance leads to extra-role behavior. It is predicted that employees with high self-efficacy will be willing to exercise extrarole behavior compared to those with low self-efficacy which tend to be pessimistic and in despair. The research conducted by Pavalache-llie (2014) showed that self-efficacy has connection with the occurrence of extra-role behavior. Other research results of Duyar, Ras, and Pearson (2015); Caesensa and Stinglhamberb (2014) also proved the same thing. Therefore, the statement about the inter-relationship between these two variables is that selfefficacy has positively influenced toward extra-role behavior.

Spiritual Motivation and Extra-Role Behavior. Motivation owned by people who is mature and emotionally healthy is something that droves them to do something based on their own will or autonomous. One of the ways to understand people's motivation is by investigating why people behave in a specific way at the time being (Schultz \& Schultz, 2013). It includes the movitivation to exercise extra-role behavior. As shown by Ibrahim and 
Aslinda (2014), their research result about intrinsic and extrinsic motivation toward extra-role behavior shows that both of them are influencing extra-role behavior; but intrinsic motivation has greater influence than extrinsic. Research result about public service motivation toward extra-role behavior shows that public service motivation has direct and positive influence toward interpersonal extra-role behavior (Pandey, 2008) and overall extra-role behavior (Xiaogang Cun, 2012).

In spiritual motivation, the dimension of mu'amalah is a broad sense of worship which is rules that set the relationship between humans, and human with object or natural material. Mu'amalah regulates primary needs (basic living needs) and secondary needs (pleasure) which are still in the corridor, to increase effort and performance activity. Adam's research result (2010) showed that spiritual motivation has influence toward extra-role behavior. Thus, it can be said that spiritual motivation has positive influence toward extra-role behavior.

Servant Leadership, Personality and Extra-Role Behavior. Servant leadership at work environment means helping other people to achieve common goals by facilitating individual's development, empowerment, and consistent collective work for long term health and prosperity of the followers. It is possible that leader's integrity and concern toward subordinate can increase their trust, loyalty and satisfaction toward their leader (Yukl, 2013). Therefore, employees that are directed by the leader with servant leadership way will be encouraged to develop extra-role behavior. It is proven by Harwiki (2016), Chiniara and Bentein (2016), and also Mahembe and Engelbrecht (2014), where the research result shows that servant leadership style significantly affect the extra-role behavior. Servant leadership influences the extra-role performance of sales workers toward consumers which is mediated by orientation competition toward customers (Jaramillo, 2009). Won Jun Kwak and Hwan-Kyung Kim (2015) found that servant leadership style of supervisor is positively related to the perception of customers toward service quality, and this relation is mediated by employee's extra-role behavior, both in individual and group level.

Based on many empirical evidences, it shows that leadership style plays a significant role toward organization's performance (Sashkin, 2014). Kondalkar (2007) stated that leadership is an influence, a process to influence a group of people in order to make them fight passionately with their own will to achieve group's purposes. This opinion is emphasizing on the social interaction and relation happened in group or organization. Leadership is described as 'social influence process where people can get help and support from other people in finishing common task'. Based on these opinions, it can be concluded that servant leadership style will have a role in the organization's performance, especially extra-role behavior, in form of influence. How leaders influence the employees so that with their personality, employees will be moved to have effective work behavior. Based on this, thus the model that shows relation between employee's personality variable, servant leadership style and extra-role behavior can be stated as follow: servant leadership plays as moderator of agreeableness, conscientiousness, self-efficacy, and spiritual motivation that influences employee's extra-role behavior.

\section{CONCLUSION}

Employees with high extra-role behavior are needed by organization to increase the organization's effectiveness. Extra-role behavior model is affected by employee's internal factor and external process of organizational environment. The most decisive employee's internal factor in the occurrence of extra-role behavior is the employee's personality. Personality traits possessed by employees that tend to influence the occurence of extra-role behavior are agreeableness and conscientiousness. These traits supported by self-efficacy and spiritual motivation as personality that is formed as advanced process of people in viewing their future. Group environment factor plays important role in forming extra-role behavior. The role of superior's leadership helps in directing employees to form extra-role behavior which is expected by organization. 


\section{REFERENCES}

1. Adam, L.B. 2011. Peran Motivasi Spiritual Agamis terhadap Organizational Citizenship Behavior dan Kinerja Dosen. Doctoral Dissertation, FEB Universitas Brawijaya, Indonesia.

2. Afshardoust, M., Feizabadi, M.S., Zakizadeh, B., \& Abdolhoseyni, M. 2013. Relationship between Organizational Citizenship Behaviour and Organizational Perceived Politic among the Sport Organization Experts of Tehran Municipality. International Research Journal of Applied and Basic Sciences.

3. Ahmadizadeh, Z., Heydarinejad, S., Farzam, F., \& Boshehri, N.S. 2012. Investigation the Relation between Organizational Climate and Organizational Citizenship Behavior. International Journal of Sport Studies, 2 (3), 163-167.

4. Alfes, K., A.D. Shantz, C. Truss and E.C. Soane. 2013. The link between perceived human resource management practices, engagement and employee behaviour: A moderated mediation model.The International Journal of Human Resource Management,Vol. 24, No. 2, 330-351.

5. Babcock-Roberson, M.E \& O.J. Strickland. 2010. The Relationship Between Charismatic Leadership, Work Engagement, And Organizational Citizenship Behaviors. The Journal of Psychology, 1444 (3), 313 - 326.

6. Bourdage, J.S., Kibeom Lee, Jong-Hyun Lee, \& Kang-Hyun Shin. 2012. Motives for Organizational Citizenship Behavior: Personality Correlates and Coworker Ratings of OCB. Human Performance, 25:179-200.

7. Burger, J.M. 2011. Personality $-8^{\text {th }}$ Edition. Wadsworth, Cengage Learning: California.

8. Caesensa, G, and F. Stinglhamberb. 2014. The relationship between perceived organizational support and work engagement: The role of self-efficacy and its outcomes. Revue européenne de psychologie appliquée, 64, 259-267.

9. Changquan Jiao and T. Hardie. 2009. Nationality, cultural values and the relative importance of task performance and organizational citizenship behaviour in performance evaluation Decisions. Journal of Comparative Management, Vol. 12 No. 1, p. $17-28$.

10. Cheng Ling Tai, Che-Ming Chang, Jhao-Yu Hong, Li-Chun Chen. 2012. Alternative models for the relationship among leadership, organizational citizenship behavior, and performance: a study of new product development teams in Taiwan. Procedia - Social and Behavioral Sciences, 57, $511-517$.

11. Chin-Yi Chen \& Chin-Fang Yang. 2012. The Impact of Spiritual Leadership on Organizational CitizenshipBehavior: A Multi-Sample Analysis. Journal of Business Ethics.105:107-114

12. Chiniara, M., and K. Bentein. 2016. Linking servant leadership to individual performance: Differentiating the mediating role of autonomy, competence and relatedness need satisfaction. The Leadership Quarterly, 27, 124-141.

13. Darsana, M. 2013. The Influence of Personality Culture on Employee Performance through Organizational Citizenship Behavior. The International Journal of Management, 2 (4), $35-42$.

14. Debusscher, J., J. Hofmans, and F. De Fruyt. 2016. The multiple face(t)s of state conscientiousness: Predicting task performance and organizational citizenship behavior. Journal of Research in Personality.

15. Dessler, G. 2014. Fundamentals of Human Resource Management - Third Edition. Pearson Education Limite: England.

16. Djati, S.P. 2008. Variabel Anteseden dan Pengaruhnya terhadap Service Quality. Disertasi PDIM, FEB Universitas Brawidjaya: Malang.

17. Duyar, I., N. Ras, and C.L. Pearson. 2015. Analysis of teachers' task and extra-role performance under different autonomy regimes. International Journal of Productivity and Performance Management, Vol. 64 No. 4, 499-522.

18. Farooqui, M.R. 2012.Measuring Organizational Citizenship Behavior (OCB) as a Consequence of Organizational Climate (OC). Asian Journal of Business Management, 4 (3), 294-302. 
19. Hall, A.T., R. Zinko, A.A. Perryman, \& G.R. Ferris. 2009. Organizatiomal Citizenship Behavior and Reputation : Mediators in the Relationship Between Accountability and Job Performance and Satisfaction. Journal of Leadership \& Organizational Studies, 15 (4), $381-392$

20. Harwiki, W,. 2016. The Impact of Servant Leadership on Organizational Culture, Organizational Commitment, Organizational Citizenship Behaviour (OCB) and Employee Performance in Women Cooperatives. Procedia - Social and Behavioral Science, 219, $283-290$.

21. Herman. 2013. Pengaruh Keadilan Organisasi, Kepribadian, Kepercayaan pada Atasan dan Komitmen organisasional terhadap OCB Perawat. Disertasi PDIM, FEB Universitas Brawidjaya: Malang.

22. Hwee Hoon Tan \& Min Li Tan. 2008. Organizational Citizenship Behavior And Social Loafing: The Role Of Personality, Motives, And Contextual Factors. The Journal of Psychology, 142 (1), 89-108.

23. Ibrahim, M.A. and Aslinda. 2014. The Effect of Motivation on Organizational Citizenship Behavior (OCB) at Telkom Indonesia in Makassar. International Journal of Administrative Science \& Organization, Vol.21, No. 2.

24. Indrawati, N.K. 2012. Manajemen Risiko Berbasis Spiritual Islam (Studi Kasus Pengelolaan Bisnis Di Pondok Pesantren Sunan Drajat Lamongan). Disertasi PDIM, FEB Universitas Brawidjaya: Malang.

25. Ismail, V.Y., E. Zain, \& Zulihar. 2015. The optimization of Human Resource's Performance in Islamic Microfinance Institutions through Job Analysis and Competency Model. The Asian Journal of Technology Management, 8 (1), 56 - 67.

26. Ivanko, I. 2012. Organizational Behavior. University of Ljubljana, Faculty of Public Administration.

27. Jaramillo, F., D.B. Grisaffe, L.B. Chonko, and J. A. Roberts. 2009. Examining The Impact Of Servant Leadership On Sales Force Performance. Journal of Personal Selling \& Sales Management, XXIX (3), 257-275.

28. Jain, A.K., \& Cooper, C.L. Stress and organisational citizenship behaviours in Indian business process outsourcing organisations, IIMB Management Review, 24, 155 - 163.

29. Kiffin-Petersen, S.A., C.L. Jordan, G.N. Soutar. 2011. The big five, emotional exhaustion and citizenship behaviors in service settings: The mediating role of emotional labor. Personality and Individual Differences, 50, 43-48.

30. Kondalkar, V.G. 2007. Organizational Behaviour. New Age International Publisher: New Delhi.

31. Larsen, R.J. \& D.M. Buss. 2010. Personality Psychology: Domains of Knowledge about Human Nature - Fourth Edition. McGraw-Hill: New York.

32. Leephaijaroen, S. 2016. Effects of the big-five personality traits and organizational commitments on organizational citizenship behavior of support staff at Ubon Ratchathani Rajabhat University, Thailand. Kasetsart Journal of Social Sciences.

33. Magdalena, S.M. The effects of organizational citizenship behavior in the academic environment, Procedia - Social and Behavioral Sciences, 127, 738 - 742.

34. Mahdiuon, R., Ghahramani, M., \& Sharif; A.R. Explanation of organizational citizenship behavior with personality. Procedia Social and Behavioral Sciences, 5,178-184.

35. Mahembe, B., and A.S. Engelbrecht. 2014. The relationship between servant leadership, organisational citizenship behaviour and team effectiveness. SA Journal of Industrial Psychology/SA Tydskrif vir Bedryfsielkunde, 40 (1).

36. Mayfield, C.O., \& Taber, T.D. 2010. A prosocial self-concept approach to understanding organizational citizenship behavior. Journal of Managerial Psychology, 25 (7), 741-763.

37. Newman, A., K. Kiazad, Qing Miao, \& B.Cooper. 2014. Examining the Cognitive and Affective Trust-Based Mechanisms Underlying the Relationship Between Ethical Leadership and Organisational Citizenship: A Case of the Head Leading the Heart? Journal of Business Ethics,123,113-123. 
38. Ning Hongyu, Zhou Mingjian, Lu Qiang and Wen Liqun. 2012. Exploring relationship between authority leadership and organizational citizenship behavior in Chin : The role of collectivism. Chinese Management Studies, 6 (2), 231-244.

39. Organ, D., Podsakoff, P., \& MacKenzie, S.B. 2006. Organizational citizenship behavior: Its nature, antecedents, and consequences. Thousand Oaks, CA: Sage.

40. Organ, D.W. 1988. Organizational citizenship behavior: The good soldier syndrome. Lexington Books: Lexington..

41. Pandey, S.K. 2008. Public Service Motivation And Interpersonal Citizenship Behavior In Public Organizations: Testing A Preliminary Model. International Public Management Journal, 11(1), 89-108.

42. Pavalache-llie, M. 2014. Organizational citizenship behaviour, work satisfaction and employees' personality. Procedia - Social and Behavioral Sciences, 127, 489 - 493.

43. Penner, L.A. et.al. 2005. Prosocial Behavior: Multilevel Perspectives. Annual Review of Psychology, 56, 365.

44. Purba, D.E. \& A.N.L. Seniati. 2014. Pengaruh Kepribadian Dan Komitmen Organisasi Terhadap Organizational Citizenzhip Behavior. Makara Sosial Humaniora, 8 (3), 105-111

45. Robbins, S.P \& Judge, T.A. 2015. Organizational Behavior $-16^{\text {th }}$ Edition. Pearson Education : New Jersey.

46. Ryckman, R.M. 2008. Theories of Personality - Ninth Edition. Thomson Wadsworth: California.

47. Sashkin, M. Management and Leadership in HRD. 2014. In Handbook of Human Resource Development, Chalofsky, N.E., T. S. Rocco, \& M.L. Morris (Editors). John Wiley \& Sons, Inc., New Jersey.

48. Schultz D.P. \& S.E. Schultz. 2013. Theories of Personality - Tenth Edition. Wadsworth, Cengage Learning: California.

49. Sesen, H., \& Basim, N.H. 2012. Impact of satisfaction and commitment on teachers' organizational citizenship. Educational Psychology, 32 (4), 475-491.

50. Stewart, G.L. \& K.G. Brown. 2011. Human Resource Management - $2^{\text {nd }}$ Edition: Linking Strategy to Practice. John Wiley \& Sons, Inc.: Hoboken.

51. Suthardjana, W.K. 2013. Pengaruh OCB terhadap Loyalitas Pasien Melalui Kualitas Pelayanan dan Kepuasan Pasien. Disertasi PDIM, FEB Universitas Brawidjaya: Malang.

52. Tziner, A \& Sharoni, G. 2014. Organizational citizenship behavior, organizational justice, job stress, and workfamily conflict: Examination of their interrelationships with respondents from a non-Western culture. Journal of Work and Organizational Psychology, 30,35-42.

53. Vigoda-Gadot, E. 2006. Compulsory Citizenship Behavior: Theorizing Some Dark Sides Of The Good Soldier Syndrome In Organizations. Journal For The Theory Of Social Behaviour, 36 (1).

54. Wibisono, C. 2003. Pengaruh Motivasi Spiritual terhadap Kinerja Karyawan Industri Manufaktur di Batam. Disertasi Pasca Sarjana, Universitas Airlangga, Surabaya.

55. Won Jun Kwak and Hwa-Kyung Kim. 2015. Servant Leadership And Customer Service Quality At Korean Hotels: Multilevel Organizational Citizenship Behavior As A Mediator. Social Behavior and Personality, 43 (8), 1287-1298.

56. Xiaogang Cun. 2012. Public service motivation and job satisfaction, organizational citizenship behavior An empirical study based on the sample of employees in Guangzhou public sectors. Chinese Management Studies, Vol. 6 No. 2, 330-340.

57. Yukl, G.. 2013. Leadership in Organizations - Eight Edition. Pearson Education: England.

58. Zheng-long Peng, \& Hong-dan Zhao. 2012. Does organization citizenship behavior really benefit the organization? : Study on the compulsory citizenship behavior in China. Nankai Business Review International, 3 (1), 75-92. 